\title{
Prevalence and factors related to urinary incontinence in older adults women worldwide: a comprehensive systematic review and meta-analysis of observational studies
}

Sedighe Batmani ${ }^{1}$, Rostam Jalali ${ }^{1}$, Masoud Mohammadi ${ }^{*}$ (i) and Shadi Bokaee ${ }^{2}$

\begin{abstract}
Background: Urinary incontinence is a common condition in the general population and, in particular, the older adults population, which reduces the quality of life of these people, so this study aims to systematically examine and meta-analyse the overall prevalence of urinary incontinence in older women around the world and the related and influential factors.
\end{abstract}

Methods: This report is a comprehensive systematic review and meta-analysis of the findings of research on urinary incontinence in older adults people across the world through looking for MEDLINE, Cochrane Library Sciencedirect, Embase, Scopus, ProQuest and Persian databases, namely iranmedex, magiran, and SID from January 2000 to April 2020, the heterogeneity of the experiments was measured using the $\mathrm{I}^{2}$ index and the data processing was done in the Systematic Meta-Analysis programme.

Results: In 29 studies and the sample size of 518,465 people in the age range of 55-106 years, urinary incontinence in older adults' women in the world based on a meta-analysis of $37.1 \%(95 \% \mathrm{Cl}$ : 29.6-45.4\%) was obtained. The highest prevalence of urinary incontinence was reported in older adults' women in Asia with $45.1 \%$ (95\% Cl: $36.9-$ 53.5\%). Meta-regression also showed that with increasing the sample size and year of the study, the overall prevalence of urinary incontinence in the older adults women of the world decreased and increased, respectively, which were statistically significant differences $(P<0.05)$. According to studies, the most important factors influencing the incidence of urinary incontinence in older women are women's age $(p<0.001)$, obesity $(p<0.001)$, diabetes $(p<0.001)$, women's education $(p<0.001)$, delivery rank $(p<0.001)$, hypertension $(p<0.001)$, smoking $(p<0.001)$. They also have urinary tract infections $(p<0.001)$.

Conclusion: Given the high prevalence of urinary incontinence in older women around the world, health policy makers must consider control and diagnostic measures in older women and prioritize treatment and rehabilitation activities.

Keywords: Prevalence, Urinary incontinence, Women, Older adults, Meta-analysis

* Correspondence: masoud mohammadi1989@yahoo.com

'Department of Nursing, School of Nursing and Midwifery, Kermanshah University of Medical Sciences, Kermanshah, Iran

Full list of author information is available at the end of the article

C The Author(s). 2021, corrected publication 2022. Open Access This article is licensed under a Creative Commons Attribution 4.0 International License, which permits use, sharing, adaptation, distribution and reproduction in any medium or format, as long as you give appropriate credit to the original author(s) and the source, provide a link to the Creative Commons licence, and indicate if changes were made. The images or other third party material in this article are included in the article's Creative Commons licence, unless indicated otherwise in a credit line to the material. If material is not included in the article's Creative Commons licence and your intended use is not permitted by statutory regulation or exceeds the permitted use, you will need to obtain permission directly from the copyright holder. To view a copy of this licence, visit http://creativecommons.org/licenses/by/4.0/. The Creative Commons Public Domain Dedication waiver (http//creativecommons.org/publicdomain/zero/1.0/) applies to the data made available in this article, unless otherwise stated in a credit line to the data. 


\section{Background}

The World Health Organization (WHO) finds citizens 65 years of age to be older adults and the United Nations deems people with 60 years or above to be older adults $[1,2]$. The world's population is aging rapidly, with 703 million people now over the age of 65 , and this number is projected to reach 1.5 billion by 2050 [3]. Urinary incontinence is a common condition in the general population, especially the older adults, which reduces the quality of life so that ten to $20 \%$ of all women and $77 \%$ of women living in nursing homes have urinary incontinence [4]. According to the International Association of Urinary Incontinence (ICS), any involuntary leakage of urine is called urinary incontinence (UI) [5].

Urinary incontinence is divided into three categories: stress, urgency and combination. Stress urinary incontinence (SUI) refers to the leakage of urine due to increased intra-abdominal pressure such as exercise and cough, which is due to the poor functional urethra. In connection with the reduction of anatomical support due to trauma, vaginal delivery, obesity and increased intraabdominal pressure due to chronic constipation, lifting heavy objects and exercise is called urinary excretion with or above the distance after the sensation of excretion, urgent urinary incontinence (UUI) Called; If both urgency and stress are present together, it is called a hybrid type (MUI) $[6,7]$.

Urinary incontinence has been identified as a World Health Organization health priority [8]. Urinary incontinence has many physical, mental and social effects on women's lives $[9,10]$, common mental problems in these people include anxiety and depression [11, 12]. Physical consequences include pressure sores [12], sleep disturbances and decreased sleep quality [13], urinary tract infections [14], falls and fractures, which are the leading causes of death in people over 65 [15].

Urinary incontinence has a great impact on daily and social activities such as work, travel, physical exercise and sexual function $[16,17]$ and thus reduces the quality of life [18]. Urgent incontinence is more common in nervous system disorders such as Parkinson's, multiple sclerosis, and spinal and pelvic nerve damage $[19,20]$. Age-related changes in the lower urinary tract include decreased bladder capacity and a feeling of fullness, decreased detrusor muscle contraction rate, decreased pelvic floor muscle strength, and increased residual urine volume [21].

The prevalence of urinary incontinence among older women has been reported in different studies, with an overall prevalence of $14 \%$ in US studies [22, 23]. In studies conducted in European countries, the prevalence of urinary incontinence has been estimated at 37\% [24, 25]. In studies conducted in different regions of Asia, the prevalence of urinary incontinence in older adults was estimated at $13 \%$ [26, 27] and in Africa 45.3\% [28]. In the study conducted in Middle Eastern countries, the prevalence of urinary incontinence was reported to be $52 \%$ [29-31].

In a study conducted in Iran, in a study in northern Iran (2016), one-third of older adults' women in the city of Babol had urinary incontinence [32], in a study conducted in Yazd (2015) among women over 60 years, the prevalence of urinary incontinence was $62.2 \%$ [31]. Given the different prevalence reported and the need for consistent doses for intervention measures, and given that women cannot avoid aging and childbirth, awareness of the risk factors for urinary incontinence should be promoted.

On the other hand, studies in this field provide opaque and different information and the effective factors affecting urinary incontinence in older adults women in different studies report different reporting amounts and heterogeneity. Therefore, this study aims to answer the questions of the prevalence of urinary incontinence in older women in the world and what are the factors affecting this incontinence?

\section{Methods \\ Registration number}

This study has been registered with the code (IR.KUMS.REC.1399.455), in the deputy of research and technology of Kermanshah University of Medical Sciences.

\section{Search method and time domain}

This study is a systematic review and meta-analysis and is the result of extracting the findings of studies conducted in this field. First, articles published in domestic and foreign journals were retrieved by searching in databases, MEDLINE, Cochrane Library, Sciencedirect, Embase, Scopus, ProQuest, and Persian databases including iranmedex, magiran and SID in the period January 2000 to April 2020.

The researcher uses the keywords urinary incontinence, women, the older adults, urinary disorders, or similar words in Persian sources and examines Englishlanguage databases using the words: Incontinence, women, older adults, urinary disorders, Prevalence, risk factor Urinary.

Also in the google scholar search engine, both words will be done in Persian and English, and the AND, OR and NOT operators will be used in combination for more comprehensive access to all articles, so the OR pragmatist will be used to check common letters about a disorder such as (Urinary incontinence OR Urinary disorders OR Urinary Reflex Incontinence OR Urinary Urge Incontinence), (Older adults OR Aging). 
As well as the word AND among the keywords: (Urinary incontinence AND older adults AND Women) will be used through word matching in the $\mathrm{MeSH}$ Browser.

Each article was read by two browsers independently and if the article was rejected, the reason for its rejection was mentioned and in case of disagreement between the two browsers, the article was judged by the third browser and the third referee was considered. Prevalence of study disorder based on PRISMA diagram for entering meta-analysis and to manage articles and remove duplicate articles the EndNote software has been used (version X7, for Windows, Thomson Reuters).

\section{Selection criteria and entry and exit criteria}

Articles in Persian and English are taken from crosssectional studies as well as case-control articles, all in the group to select the factors affecting urinary incontinence in older adults' women had the selection criteria to enter the study. And review articles, articles that do not have access to full text despite the relationship with the author of the article and lack of proper response, as well as articles that are of low quality in the evaluation of quality evaluation were removed from the review list.

\section{Quality assessment and evaluation of the risk of bias}

The Newcastle-Ottawa Scale (NOS) is a quality assessment tool for observational studies that are recommended by the Cochrane Collaboration [21]. The NOS assigns up to a maximum of nine points for the least risk of bias in three domains: 1) selection of study groups (four points); 2) comparability of groups (two points); and 3) ascertainment of exposure and outcomes (three points) for case-control and cohort studies, respectively [21], and 11 scores possible. Eventually, articles were classified as high quality (scoring $\geq 5$ points) or low quality (scoring $<5$ points). In this meta-analysis, all the articles that obtained five or more points were included.

\section{Statistical analysis}

Data were analysed using Comprehensive Meta-analysis software (Biostat, Englewood, NJ, USA version 3). To evaluate the heterogeneity of selected studies, the $\mathrm{I}^{2}$ index test was used. If high heterogeneity is obtained in studies $\left(75 \%<\mathrm{I}^{2}\right)$, random effects model will be used for meta-analysis of studies, and if low heterogeneity is obtained $\left(\mathrm{I}^{2}<25 \%\right)$, the fixed effects model will be used for the analysis of studies [21]. also, to investigate the publication bias and regarding the high volume of samples included in the study, The Begg and Mazumdar test and its corresponding Funnel plot were used at a significance level of 0.1 . the meta-regression test was used to investigate the effects of potential factors influencing the heterogeneity of the studies.

\section{Results}

\section{Search output}

Based on studies on the prevalence and factors related to urinary incontinence in older women and including articles published in domestic and foreign journals and search in Cochrane Library Sciencedirect, Embase, Scopus, ProQuest and Persian databases including iranmedex, magiran and SID and in total searches: 2791 items were found. Then, the articles that had the initial conditions for inclusion in the study, based on the initial reviews by deleting 2522 duplicate articles and deleting 235 articles unrelated to the subject of study and deleting 5 articles during the secondary reviews due to lack of access to abstracts and main articles and low quality of articles (This number of deleted items from articles due to lack of access to the full text of articles and their abstracts due to being old or removed from the site of some journals and also their low quality in quality evaluation, of course, the deleted items due to low quality in the study is very limited.). The article entered the meta-analysis process (Fig. 1) (Table 1).

\section{Review of publication bias and meta-analysis}

The heterogeneity of the studies was investigated using the $\mathrm{I}^{2}$ test and based on this test, the amount of heterogeneity $\left(\mathrm{I}^{2}=99.9 \%\right)$ was obtained and shows high heterogeneity in the included studies, so the random-effects model was used to combine the results of the studies. Also, the results of the study of publication bias in the studies were evaluated due to the high sample size entered in the studies with Begg and Manzumdar test and with a significance level of 0.1 , which indicates that the diffusion bias was not significant in the present study $(P=0.252)$ (Fig. 2).

A review of 29 studies and the sample size of 518,465 people in the age range of 55-106 years, urinary incontinence in the older adults' women of the world based on a meta-analysis of $37.1 \%$ (95\% CI: 29.6-45.4\%) was obtained. The highest prevalence of urinary incontinence in older adults' women in Egypt with 80\% (95\% CI:72.2$86 \%$ ) in 2020 [50] and the lowest prevalence of urinary incontinence in older adults' women in Mexico with $9.5 \%$ (95\% CI:8-11.2\%) was achieved in 2017 [33] (Fig. 3).

In this figure, the prevalence of urinary incontinence is shown based on the random-effects model, in which the black square, the colour of the prevalence, and the length of the line segment on which the square is placed are $95 \%$ confidence intervals in each study.

\section{Sensitivity analysis}

A sensitivity analysis was perfumed to ensure the stability results, after removing each study results did not change (Fig. 4). 


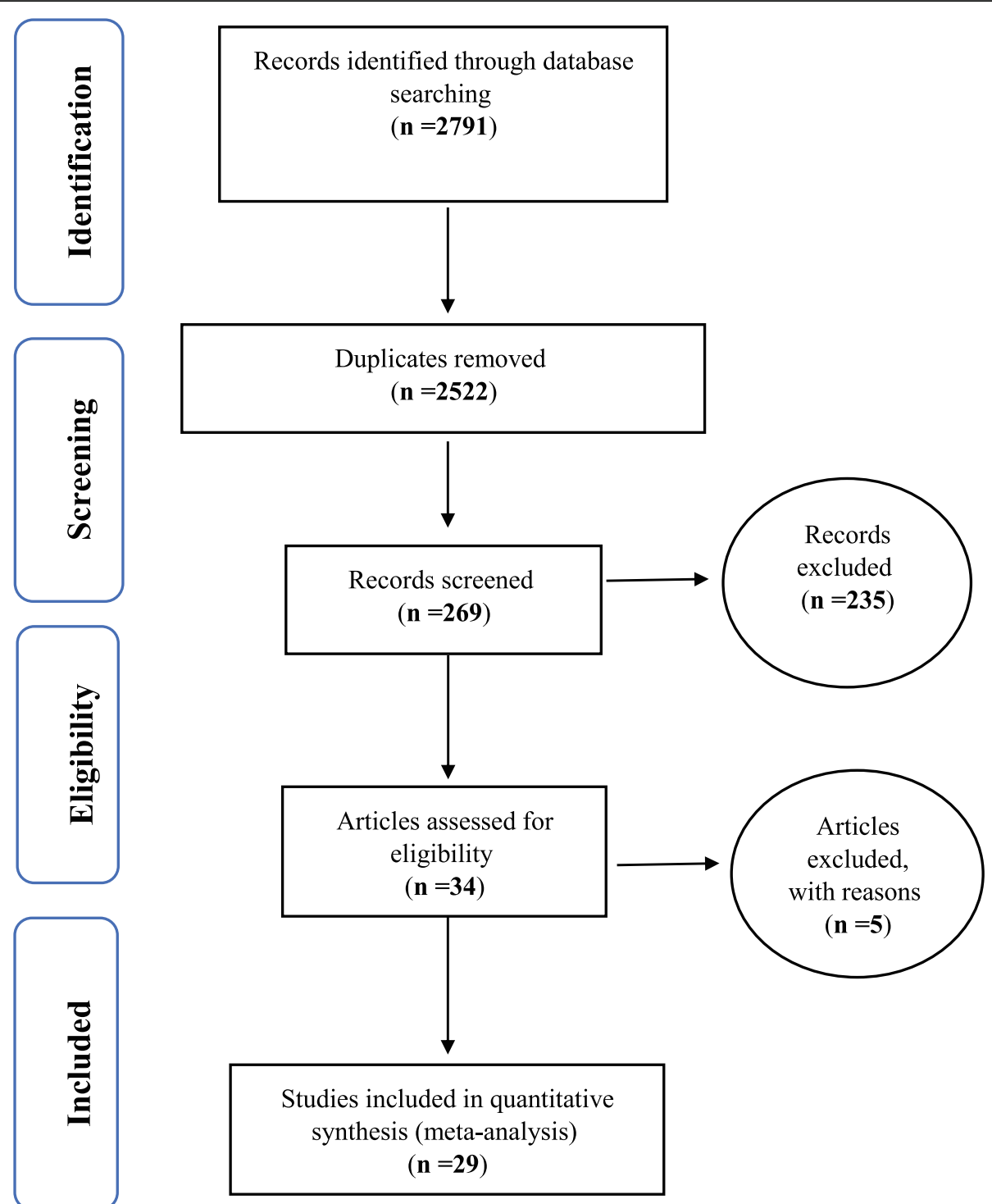

Fig. 1 The flowchart on the stages of including the studies in the systematic review and meta-analysis (PRISMA 2009)

\section{Meta-regression test}

To investigate the effects of potential factors influencing the heterogeneity of the overall prevalence of urinary incontinence in older women around the world, metaregression was used for two factors: sample size and year of study (Figs. 5 and 6). According to Fig. 5, with increasing sample size, the overall prevalence of urinary incontinence in the older adults omen of the world decreases $(P<0.05)$. It was also reported in Fig. 6 that with increasing the year of the study, the overall prevalence of urinary incontinence in the older adults women of the world increases $(P<0.05)$.

\section{Subgroup analysis by continent}

Based on the results of Table 2, the highest prevalence of urinary incontinence in older adults women was reported in Asia with 45.1\% (95\% CI: 36.9$53.5 \%)$. The results of this table also report that no diffuse bias was observed in the study by continent, and the study of metallic mercury was also reported in each continent.

\section{Effective and related factors in urinary incontinence in older adults' women}

According to a systematic review of studies, various factors affect the incidence of urinary incontinence in older women, the most important of which are the age of women $[25,26,38,49,50,58-64]$, obesity based on BMI index [25, 37, 48, 49, 52, 58, 59, 62, 63, 65-67], diabetes $[25,26,37,49,52,58,62,66-68]$, women's education $[26,30,36,48,52,58,61]$, delivery rate $[23$, $37,59,60,62,67]$, hypertension [26, 66, 67], smoking 
Table 1 Specifications of studies entered the study

\begin{tabular}{|c|c|c|c|c|c|c|c|}
\hline Row & Author [References] & Publication year & Area & Participants' Age & Sample size & Prevalence & Quality assessmen \\
\hline 1 & Ma_gfiret Kaşıkçıa [29] & 2015 & Turkey & $\geq 65$ & 1094 & 51.6 & Moderate \\
\hline 2 & Mary K. Townsend [33] & 2017 & Mexico & $\geq 60$ & 1289 & 9.5 & Moderate \\
\hline 3 & Samreen Khan [30] & 2017 & India & $\geq 60$ & 149 & 46.3 & Moderate \\
\hline 4 & Larissa Pruner Marques [23] & 2015 & Brazil & $\geq 60$ & 1089 & 36.3 & High \\
\hline 5 & E. Moudi [34] & 2017 & Iran & $\geq 60$ & 590 & 32.9 & High \\
\hline 6 & Khanighaleejogh R [35] & 2011 & Iran & $68-84$ & 114 & 54.2 & Moderate \\
\hline 7 & David V. Espino [36] & 2003 & USA & $\geq 65$ & 1589 & 15 & Moderate \\
\hline 8 & Stefania Maggi [37] & 2001 & Italy & $\geq 65$ & 1531 & 21.6 & Moderate \\
\hline 9 & Yu Ko [38] & 2005 & USA & $\geq 65$ & 58,255 & 27.5 & Moderate \\
\hline 10 & Jing Ge [39] & 2015 & China & $\geq 60$ & 627 & 22.1 & High \\
\hline 11 & Juliana Schulze Burti [40] & 2012 & Brazil & $\geq 65$ & 246 & 50 & Moderate \\
\hline 12 & Rochani Sumardi [41] & 2014 & Indonesia & $\geq 60$ & 273 & 24.2 & Moderate \\
\hline 13 & Gileard G. Masenga [42] & 2019 & Tanzania & $55-90$ & 274 & 48.5 & Moderate \\
\hline 14 & Jennifer M. Wu [43] & 2015 & USA & $\geq 60$ & 2423 & 20.6 & Moderate \\
\hline 15 & Mary K. Townsend [33] & 2017 & Mexico & $\geq 60$ & 1168 & 10.3 & Moderate \\
\hline 16 & Lei Zhang [44] & 2014 & China & $\geq 60$ & 3753 & 51.6 & Moderate \\
\hline 17 & Jarosław Pinkas [45] & 2016 & Poland & $90-106$ & 870 & 60 & High \\
\hline 18 & Javier Jerez-Roig [46] & 2016 & Brazil & $\geq 60$ & 240 & 40.8 & Moderate \\
\hline 19 & Renata B. Reigota [47] & 2016 & Brazil & $\geq 60$ & 379 & 53.6 & Moderate \\
\hline 20 & Nazli Sensoy [48] & 2013 & Turkey & $\geq 60$ & 203 & 29.3 & High \\
\hline 21 & J. Marleen Linde [49] & 2017 & Netherlands & $\geq 60$ & 189 & 56.6 & Moderate \\
\hline 22 & Walaa W. Aly [50] & 2020 & Egypt & $\geq 60$ & 130 & 80 & Moderate \\
\hline 23 & Prabhu, Shruti Atul [51] & 2013 & India & $\geq 60$ & 58 & 41.1 & High \\
\hline 24 & Bo Liu [52] & 2014 & China & $\geq 60$ & 1417 & 54.2 & Moderate \\
\hline 25 & Pamela L [53] & 2013 & Canada & $\geq 65$ & 331,000 & 14 & High \\
\hline 26 & Rui Luo [54] & 2017 & Singapore & $\geq 60$ & 22 & 59.09 & High \\
\hline 27 & Catherine A. Matthews [55] & 2013 & America & $62-87$ & 64,396 & 38 & Moderate \\
\hline 28 & Lea F. Schumpf [56] & 2017 & Switzerland & $\geq 65$ & 44,811 & 54.7 & Moderate \\
\hline 29 & Olga NTkacheva [57] & 2018 & Russia & $\geq 65$ & 286 & 40.2 & High \\
\hline
\end{tabular}

$[30,36,37,52,60,62]$ as well as urinary tract infections $[23,49,52]$. Based on the results reported in Table 3, all these factors have a significant difference in the incidence of urinary incontinence in older adults' women $(p<0.05)$.

\section{Discussion}

Urinary incontinence is a very common condition that usually increases with age in women. Having general information about the prevalence of this disorder and identifying risk factors is useful and even necessary that can play an effective role in improving the quality of life and general health of society $[4,57]$. This meta-analysis study was performed on 518,465 older adults women and the prevalence of urinary incontinence in older adults women was $37.1 \%$. However, in the study of the prevalence of incontinence in older adults women by continents, the highest prevalence of urinary incontinence was reported in older adults women in Asia with 45.1\%.

In a study conducted in Egypt (2020), the prevalence of incontinence among older women was $80 \%$ [50]. In the study of Summer Khan et al. in India (2018) the overall prevalence of urinary incontinence was $46.3 \%$ [30], in a study in Russia (2018) the prevalence of incontinence in older adults women was 40.2 [57].

In a study conducted in Iran (2017), it was reported that one-third of older women (33\%) have urinary incontinence [34]. In another study conducted in Iran as a systematic review and meta-analysis (2018), the overall prevalence of urinary incontinence in women was estimated at $46 \%$ [64]. 


\section{Funnel Plot of Standard Error by Logit event rate}

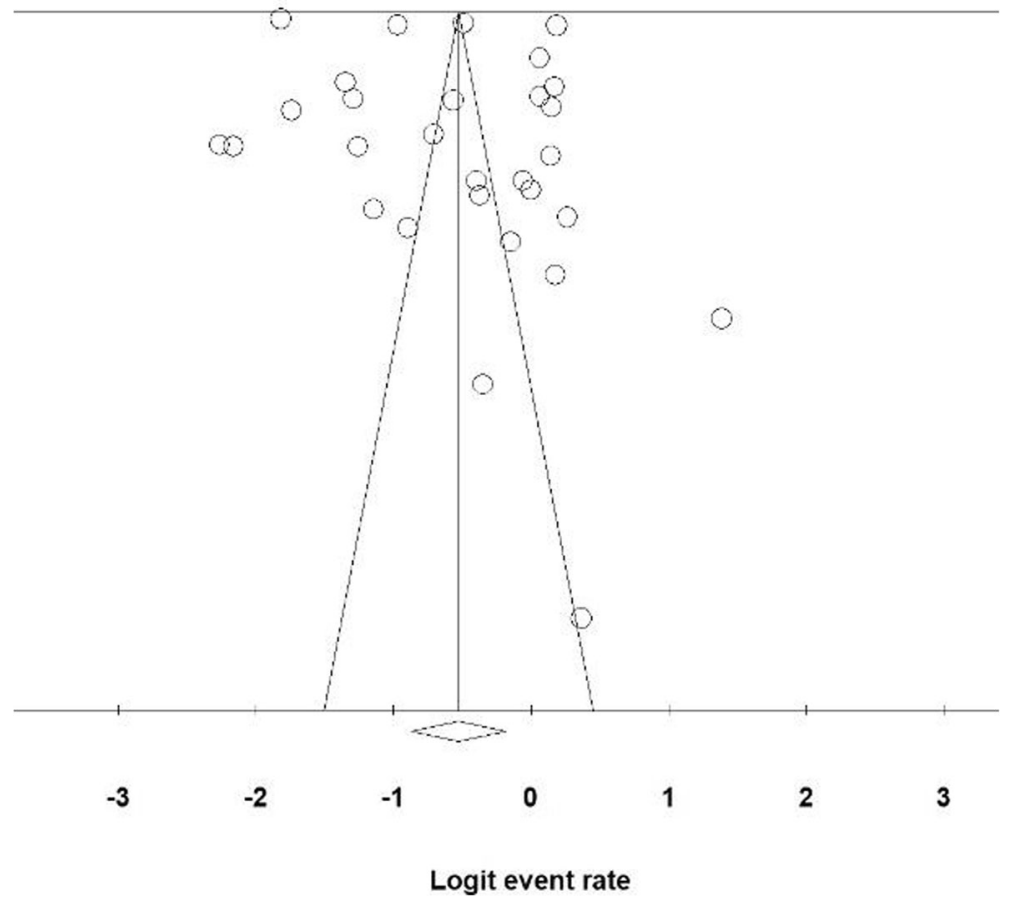

Fig. 2 Funnel Plot Results of urinary incontinence in older adults' women worldwide

Based on the results, the highest prevalence of urinary incontinence in older adults' women was reported in Asia with $45.1 \%$ and the lowest prevalence of urinary incontinence in older adults' women was reported in America with 25.8\%, By observing the prevalence in different regions, it can be concluded that the prevalence of urinary incontinence in different populations is completely different, which can be due to differences in culture or tools and methods of study.

It can also show the effect of ethnoreligious factor on the insignificance of urinary incontinence in older adults' women in Asian countries, this issue has been stated and reported in the study of Touhidi Nezhad and et al. this study is about rectovaginal fistula and explains the importance and says that The rectovaginal fistula is a complex and multifaceted problem with social, individual, familial, religious, and ethnic-environmental dimensions [69], this can embarrass Asian women and hide and increase the prevalence of urinary incontinence in older women.

The high prevalence obtained in this study shows the need to investigate and follow up this condition, due to the significant impact of this disorder on depression and quality of life of older adults' women, requires special attention and screening for urinary incontinence in treatment and care programs in the country. Various studies have mentioned various factors in the incidence of urinary incontinence in women, such as age, menopause, delivery and number of deliveries, obesity, and diabetes are among the most important of these factors [25, 70].

Age is one of the important factors in the prevalence of urinary incontinence. Changes related to aging in the lower urinary system include: decreased bladder capacity and feeling of fullness, decreased rate of detrusor muscle contraction, decreased pelvic floor muscle resistance and increased residual urine volume [21].

In a study by Marland Lind et al. in the Netherlands and a study by Nazli et al. in Turkey, aging was one of the most influential factors in urinary incontinence [48, 49], while in a study in Brazil [46] In Iranian older adults women, no relationship was observed between urinary incontinence and aging [34]. Menopause, with a decrease in estrogen and a decrease in collagen, reduces the elasticity of the detrusor muscle of the ductus arteriosus and atrophic changes in the pelvic floor muscles and increases urinary incontinence in women [71].

In the study conducted in Turkey, menopause is one of the most important factors influencing female 


\begin{tabular}{lcccrrr}
\hline Study name & \multicolumn{5}{c}{ Statistics for each study } \\
\cline { 1 - 6 } & $\begin{array}{c}\text { Event } \\
\text { rate }\end{array}$ & $\begin{array}{l}\text { Lower } \\
\text { limit }\end{array}$ & $\begin{array}{c}\text { Upper } \\
\text { limit }\end{array}$ & Z-Value & p-Value \\
Ma_gfiret & 0.516 & 0.486 & 0.545 & 1.028 & 0.304 \\
Mary K. Townsend & 0.095 & 0.080 & 0.112 & -23.733 & 0.000 \\
Samreen Khan & 0.463 & 0.385 & 0.543 & -0.900 & 0.368 \\
Larissa Pruner Marques & 0.363 & 0.335 & 0.392 & -8.942 & 0.000 \\
E. Moudi & 0.331 & 0.294 & 0.370 & -8.065 & 0.000 \\
Khanighaleejogh* R & 0.544 & 0.452 & 0.633 & 0.935 & 0.350 \\
David V. Espino & 0.150 & 0.133 & 0.168 & -24.699 & 0.000 \\
Stefania Maggi & 0.216 & 0.196 & 0.238 & -20.745 & 0.000 \\
Yu Ko & 0.275 & 0.271 & 0.279 & -104.474 & 0.000 \\
Jing Ge & 0.222 & 0.191 & 0.256 & -13.062 & 0.000 \\
Juliana Schulze Burti & 0.500 & 0.438 & 0.562 & 0.000 & 1.000 \\
Rochani Sumardi1,6, & 0.242 & 0.195 & 0.296 & -8.086 & 0.000 \\
Gileard G. Masengal & 0.485 & 0.427 & 0.545 & -0.483 & 0.629 \\
Jennifer M. Wu & 0.206 & 0.191 & 0.223 & -26.833 & 0.000 \\
Mary K. Townsend1 & 0.104 & 0.087 & 0.122 & -22.474 & 0.000 \\
Lei Zhang & 0.516 & 0.500 & 0.532 & 1.975 & 0.048 \\
Jaroslaw Pinkas & 0.538 & 0.505 & 0.571 & 2.235 & 0.025 \\
Javier Jerez-Roig & 0.408 & 0.348 & 0.472 & -2.824 & 0.005 \\
Renata B. Reigota & 0.536 & 0.485 & 0.585 & 1.386 & 0.166 \\
Nazli Sensoy & 0.291 & 0.232 & 0.357 & -5.772 & 0.000 \\
J. Marleen Linde & 0.566 & 0.495 & 0.635 & 1.813 & 0.070 \\
Walaa W. Aly & 0.800 & 0.722 & 0.860 & 6.322 & 0.000 \\
Prabhu, Shruti Atul & 0.414 & 0.295 & 0.543 & -1.306 & 0.191 \\
Bo Liu & 0.543 & 0.517 & 0.568 & 3.210 & 0.001 \\
Pamela L & 0.140 & 0.139 & 0.141 & -362.388 & 0.000 \\
Rui Luo & 0.591 & 0.382 & 0.772 & 0.848 & 0.396 \\
Catherine A. Matthews & 0.380 & 0.376 & 0.384 & -60.303 & 0.000 \\
Lea F. Schumpf & 0.547 & 0.542 & 0.552 & 19.863 & 0.000 \\
Olga NTkachev & 0.402 & 0.347 & 0.460 & -3.290 & 0.001 \\
& 0.371 & 0.296 & 0.454 & -3.024 & 0.002 \\
& & & & & \\
& & & & &
\end{tabular}

\section{Event rate and $95 \% \mathrm{Cl}$}

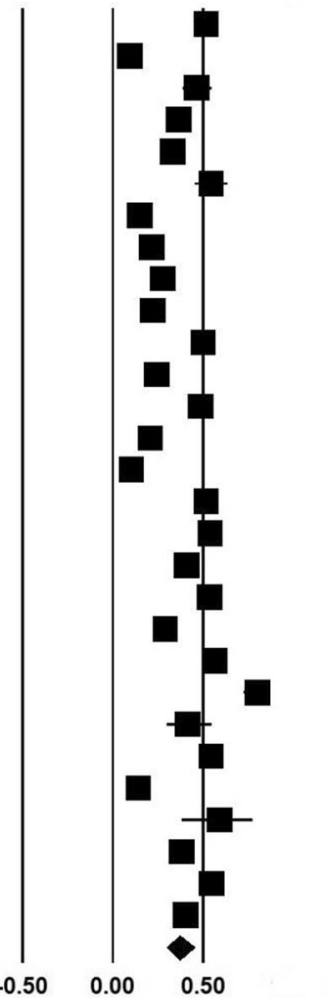

\section{Meta Analysis}

Fig. 3 Overall prevalence of urinary incontinence in older adults' women worldwide based on a random effects model

incontinence [48], while in the study of Aquarius et al. in Brazil, no significant relationship was reported between menopause and the increased prevalence of urinary incontinence [72]. Urinary incontinence is higher in women with more deliveries and vaginal deliveries. These two factors seem to be one of the most important risk factors for urinary incontinence in women [73]. In the study conducted among Chinese women, there is a type of delivery and the possibility of urinary incontinence [52], also in the study of Marland Lind et al. there was a significant relationship between delivery history, number and type of delivery with increased urinary incontinence [49]. However, in a study in India, no association was found between childbirth and urinary incontinence [30].

Obesity is an exacerbating condition of urinary incontinence, which can be caused by the accumulation of excess weight on the urinary tract during life [22]. Many studies have shown an association between obesity and increased urinary incontinence. In a study by Ninomia et al. in Japan [59] and a study by Hong et al. in the United States [74], a significant relationship was found between weight gain and increased incidence of urinary incontinence.

Also, the level of education is considered as one of the components of individual and social development and its role in personal health and also a factor in increasing the quality of life [9]. In his study by Espanyo et al. in Mexico and the United States [36] and in the study by Marcos et al. in Brazil [23], increasing the level of education was reported to be an important factor in reducing the incidence of urinary incontinence. No urinary incontinence was reported between education levels [66].

Diabetes can cause UI by several mechanisms, hyperglycaemia causes increased urine volume and increased 


\begin{tabular}{|c|c|c|c|c|c|}
\hline \multirow[t]{2}{*}{ Study name } & \multicolumn{5}{|c|}{ Statistics with study removed } \\
\hline & Point & $\begin{array}{c}\text { Lower } \\
\text { limit }\end{array}$ & $\begin{array}{l}\text { Upper } \\
\text { limit }\end{array}$ & Z-Value & $\mathrm{p}$-Val \\
\hline Ma_gfiret & 0.366 & 0.290 & 0.450 & -3.094 & 0.002 \\
\hline Mary K. Townsend & 0.386 & 0.308 & 0.471 & -2.619 & 0.009 \\
\hline Samreen Khan & 0.368 & 0.292 & 0.452 & -3.048 & 0.002 \\
\hline \multicolumn{2}{|c|}{ Larissa Pruner Marques0.372 } & 0.295 & 0.456 & -2.957 & 0.003 \\
\hline E. Moudi & 0.373 & 0.296 & 0.457 & -2.931 & 0.003 \\
\hline Khanighaleejogh & 0.366 & 0.290 & 0.449 & -3.112 & 0.002 \\
\hline David V. Espino & 0.382 & 0.304 & 0.466 & -2.719 & 0.007 \\
\hline Stefania Maggi & 0.378 & 0.300 & 0.462 & -2.806 & 0.005 \\
\hline Yu Ko & 0.376 & 0.288 & 0.473 & -2.501 & 0.012 \\
\hline Jing $G e$ & 0.378 & 0.300 & 0.462 & -2.819 & 0.005 \\
\hline Juliana Schulze Burti & 0.367 & 0.291 & 0.451 & -3.078 & 0.002 \\
\hline Rochani Sumardi1,6, & 0.377 & 0.299 & 0.461 & -2.846 & 0.004 \\
\hline Gileard G. Masengal & 0.367 & 0.291 & 0.451 & -3.066 & 0.002 \\
\hline Jennifer M. Wu & 0.378 & 0.300 & 0.463 & -2.790 & 0.005 \\
\hline Mary K. Townsend 1 & 0.385 & 0.307 & 0.470 & -2.638 & 0.008 \\
\hline Lei Zhang & 0.366 & 0.290 & 0.450 & -3.101 & 0.002 \\
\hline Pinkas & 0.366 & 0.290 & 0.449 & & 0.002 \\
\hline Javier & 0.370 & 0.293 & 0.454 & -3.002 & 0.003 \\
\hline Renata B. Reigota & 0.366 & 0.290 & 0.449 & -3.109 & 0.002 \\
\hline Nazli Sensoy & 0.374 & 0.297 & 0.459 & -2.897 & 0.004 \\
\hline J. Marleen Linde & 0.365 & 0.289 & 0.448 & -3.132 & 0.002 \\
\hline Walaa W. Aly & 0.356 & 0.281 & 0.439 & -3.350 & 0.001 \\
\hline Prabhu, Shruti Atul & 0.370 & 0.293 & 0.454 & -3.008 & 0.003 \\
\hline Bo Liu & 0.365 & 0.289 & 0.449 & -3.120 & 0.002 \\
\hline Pamela L & 0.380 & 0.330 & 0.432 & -4.393 & 0.000 \\
\hline Rui Luo & 0.365 & 0.289 & 0.448 & -3.131 & 0.002 \\
\hline Catherine A. Matthews & 0.372 & 0.287 & 0.465 & -2.676 & 0.007 \\
\hline Lea F. Schumpf & 0.364 & 0.299 & 0.435 & -3.683 & 0.000 \\
\hline \multirow[t]{2}{*}{ Olga NTkachev } & 0.370 & 0.294 & 0.454 & -2.996 & 0.003 \\
\hline & 0.371 & 0.296 & 0.454 & -3.024 & 0.002 \\
\hline
\end{tabular}

Event rate $(95 \% \mathrm{Cl})$

with study removed



\section{Meta Analysis}

Fig. 4 Results of sensitivity analysis

\section{Regression of Sample on Logit event rate}

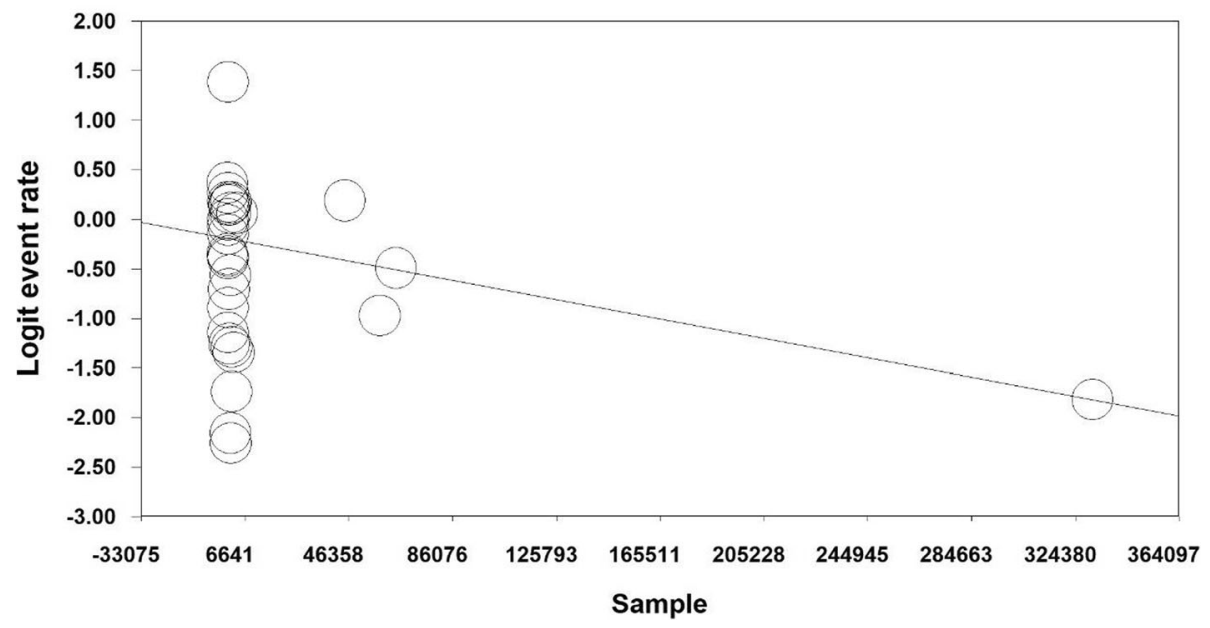

Fig. 5 Meta-regression diagram of the overall prevalence of urinary incontinence in older adults' women worldwide by sample size 




Fig. 6 Meta-regression diagram of the overall prevalence of urinary incontinence in older adults' women worldwide by year of release

activity of the bladder muscle, and ultimately causes dysfunction of this muscle. Diabetic cytopathic and bladder nerve damage are other effective complications [75]. In a study by Absen et al. in Norway, it was reported that there was a significant association between diabetes and urinary incontinence [60], while a German study found no association between diabetes and urinary incontinence [25].

Chronic respiratory diseases are associated with symptoms such as a cough that can cause urinary incontinence [76]. In a study based on the population of Jinge Ge et al. in China, a significant relationship was reported between lung disease and incidence [39]. However, in the study of Ralph Souher et al. in Germany [4] and the study of Sohan et al. in Korea [26], no significant relationship was observed between urinary incontinence and respiratory disease.

Nervous system disorders are seen as an important factor in the prevalence of urgent incontinence $[19,20]$. There were mental illnesses, cancer and conditions such as living alone [25]. A study by Kasik et al. in Turkey also reported obesity, smoking, a history of constipation, UTI, family history, chronic illness, chronic cough, a history of hormone therapy, genital prolapse, a history of urology, and a history of communication impairment. Have significance with incontinence [46].

In a promising study by colleagues in Iran, it was reported that urinary incontinence is directly and significantly related to factors such as marital status, constipation, and corticosteroid medications, while urinary incontinence is associated with factors such as age, obesity, education, number of children, diabetes, hypertension, and Respiratory disorders were not associated [34].

In a 2016 study by Aquarius et al. in Brazil, the factors that increased urinary incontinence in women included: number of pregnancies, deliveries, genital prolapse, anxiety, depression, and obesity [72]. In a study by Marcos et al. in Brazil, there was a significant relationship between age, education, physical activity, dependence, cognitive problems, symptoms of anomia, bronchitis, asthma, cardiovascular disease, diabetes, hypertension, stroke and ischemia, nutritional status, polypharmacy, self-Urinary incontinence was reported [23].

Given the above, it is necessary for physicians and specialists to consider adults' women in the age group of 55 to 106 years according to the criteria

Table 2 Evaluation of urinary incontinence in older adults' women by different continents

\begin{tabular}{|c|c|c|c|c|c|c|c|c|}
\hline \multirow[t]{2}{*}{ continents } & \multirow{2}{*}{$\begin{array}{l}\text { Number of } \\
\text { articles }\end{array}$} & \multirow{2}{*}{$\begin{array}{l}\text { Sample } \\
\text { Size }\end{array}$} & \multirow[t]{2}{*}{$\mathrm{I}^{2}$} & \multirow{2}{*}{$\begin{array}{l}\text { Begg and } \\
\text { Mazumdar Test }\end{array}$} & \multirow{2}{*}{$\begin{array}{l}\text { Prevalence \% } \\
(95 \% \mathrm{Cl})\end{array}$} & \multicolumn{2}{|c|}{ Meta-regression } & \multirow[t]{2}{*}{$p$ value } \\
\hline & & & & & & Samples & Years & \\
\hline Asia & 12 & 7419 & 97.1 & 0.394 & $45.1(95 \% \mathrm{Cl}: 36.9-53.5)$ & increase & decrease & $<0.05$ \\
\hline Europe & 6 & 48,698 & 99.1 & 0.247 & 43.8 (95\% Cl: 32.2-56.1) & increase & increase & $<0.05$ \\
\hline America & 11 & 462,074 & 99.9 & 0.535 & $25.8(95 \% \mathrm{Cl}: 18.2-35.3)$ & decrease & decrease & $<0.05$ \\
\hline
\end{tabular}


Table 3 A systematic review of the factors affecting older adults' women with urinary incontinence

\begin{tabular}{|c|c|c|c|c|}
\hline Author [References] & Place of study & type of study & Risk factors examined & $p$-value \\
\hline \multirow[t]{10}{*}{ S.A. Eshkoor 2017 [27] } & \multirow[t]{10}{*}{ Malaysia } & \multirow[t]{10}{*}{ Case-control } & Blood Triglycerides & 0.015 \\
\hline & & & Albumin & 0.026 \\
\hline & & & $\mathrm{HDL}$ & 0.029 \\
\hline & & & Monounsaturated fat & 0.009 \\
\hline & & & Cataract-glaucoma & 0.051 \\
\hline & & & Tiredness & 0.039 \\
\hline & & & Constipation & $<0.001$ \\
\hline & & & Gastric-Ulcer Problem & $<0.001$ \\
\hline & & & Vision-hearing loss & 0.010 \\
\hline & & & Joint pain & 0.002 \\
\hline \multirow[t]{12}{*}{ Shi LU et al. 2016 [65] } & \multirow[t]{12}{*}{ China } & \multirow[t]{12}{*}{ Cross-sectional } & Age & 0.041 \\
\hline & & & $\mathrm{BMl}$ & 0.027 \\
\hline & & & Menstrual status & 0.036 \\
\hline & & & Mode of delivery & 0.007 \\
\hline & & & Heart disease & 0.02 \\
\hline & & & Dyslipidemia & 0.038 \\
\hline & & & Arthritis & 0.003 \\
\hline & & & Gynecological disease & $<0.001$ \\
\hline & & & Chronic pelvic pain & $<0.001$ \\
\hline & & & Atrophic vaginitis & $<0.001$ \\
\hline & & & Constipation & $<0.001$ \\
\hline & & & Fecal incontinence & $<0.001$ \\
\hline \multirow[t]{13}{*}{ Ralf Suhr et al. 2017 [25] } & \multirow[t]{13}{*}{ Germany } & \multirow[t]{13}{*}{ Cross-sectional } & Musculoskeletal disease & 0.002 \\
\hline & & & Stroke & 0.035 \\
\hline & & & Cancer & 0.003 \\
\hline & & & Dementia & $<0.001$ \\
\hline & & & Live with barriers & 0.129 \\
\hline & & & Living alone & 0.143 \\
\hline & & & $\mathrm{BMl}$ & 0.01 \\
\hline & & & Age & 0.06 \\
\hline & & & Female sex & 0.007 \\
\hline & & & Respiratory & 0.158 \\
\hline & & & Diabetes & 0.798 \\
\hline & & & Cardiovascular & 0.002 \\
\hline & & & Psychiatric & 0.927 \\
\hline \multirow[t]{5}{*}{ Pedersen et al. 2017 [58] } & \multirow{5}{*}{$\begin{array}{l}\text { Germany and } \\
\text { Denmark }\end{array}$} & \multirow[t]{5}{*}{ Analytical descriptive } & Age & $<0.001$ \\
\hline & & & $\mathrm{BMl}$ & 0.001 \\
\hline & & & Diabetes & 0.007 \\
\hline & & & $\begin{array}{l}\text { Chronic obstructive } \\
\text { pulmonary disease }\end{array}$ & 0.002 \\
\hline & & & Vaginal deliveries & $<0.001$ \\
\hline \multirow{3}{*}{$\begin{array}{l}\text { Ma_gfiret Kaşıkçı et al. } \\
2015 \text { [36] }\end{array}$} & \multirow[t]{3}{*}{ Turkey } & \multirow[t]{3}{*}{ Cross-sectional } & $\mathrm{BMl}$ & $<0.001$ \\
\hline & & & Smoking & 0.047 \\
\hline & & & Constipation & $<0.001$ \\
\hline
\end{tabular}


Table 3 A systematic review of the factors affecting older adults' women with urinary incontinence (Continued)

\begin{tabular}{|c|c|c|c|c|}
\hline Author [References] & Place of study & type of study & Risk factors examined & $p$-value \\
\hline & & & Urinary tract infection & $<0.001$ \\
\hline & & & Chronic diseases & $<0.001$ \\
\hline & & & Familiar history & $<0.001$ \\
\hline & & & $\begin{array}{l}\text { Complaint of chronic } \\
\text { coughing }\end{array}$ & 0.530 \\
\hline & & & Hormone replacement & $<0.001$ \\
\hline & & & Genital prolapse & $<0.001$ \\
\hline & & & Cystocele & $<0.001$ \\
\hline & & & Urogenital operation & $<0.001$ \\
\hline & & & Nocturia & $<0.001$ \\
\hline \multirow[t]{13}{*}{ Kyungjin Sohn et al. 2018 [26] } & Korea & Longitudinal Study & Age & $<0.001$ \\
\hline & & & Education & $<0.001$ \\
\hline & & & Marital status & 0.043 \\
\hline & & & Chronic lung disease & 0.034 \\
\hline & & & Cerebrovascular disease ॥ & 0.002 \\
\hline & & & Social activity & 0.007 \\
\hline & & & Arthritis & $<0.001$ \\
\hline & & & $\begin{array}{l}\text { Difficulty in daily living } \\
\text { due to visual problems }\end{array}$ & $<0.001$ \\
\hline & & & $\begin{array}{l}\text { Difficulty in daily living } \\
\text { due to hearing problems }\end{array}$ & $<0.001$ \\
\hline & & & $\begin{array}{l}\text { Experience of fall in the } \\
\text { last } 2 \text { years }\end{array}$ & 0.017 \\
\hline & & & Psychiatric disease & 0.008 \\
\hline & & & Fear of falling & $<0.001$ \\
\hline & & & Psychiatric disease & 0.008 \\
\hline \multirow[t]{5}{*}{ Samreen Khan et al. 2017 [30] } & India & Cross-sectional & Years spent in menopause & 0.002 \\
\hline & & & parity & 0.001 \\
\hline & & & Hysterectomy & 0.006 \\
\hline & & & UTI & $<0.001$ \\
\hline & & & Pelvic organ prolapse & 0.031 \\
\hline \multirow[t]{5}{*}{ Sanae Ninomiya et al. 2017 [59] } & Japan & Cross-sectional & Age & $<0.001$ \\
\hline & & & BMl & $<0.001$ \\
\hline & & & parity & 0.009 \\
\hline & & & Mode of delivery & $<0.001$ \\
\hline & & & Constipation & 0.01 \\
\hline \multirow{9}{*}{$\begin{array}{l}\text { Larissa Pruner Marques et al } \\
2015 \text { [23] }\end{array}$} & Brazil & Cross-sectional & Gender & $<0.001$ \\
\hline & & & Age & $<0.001$ \\
\hline & & & Education & $<0.001$ \\
\hline & & & Physical activity & $<0.001$ \\
\hline & & & Dependence & $<0.001$ \\
\hline & & & Cognitive deficiency & $<0.001$ \\
\hline & & & Depressive symptoms & $<0.001$ \\
\hline & & & Diabetes & $<0.001$ \\
\hline & & & Bronchitis or asthma & $<0.001$ \\
\hline
\end{tabular}


Table 3 A systematic review of the factors affecting older adults' women with urinary incontinence (Continued)

\begin{tabular}{|c|c|c|c|c|}
\hline Author [References] & Place of study & type of study & Risk factors examined & $p$-value \\
\hline & & & Hypertension & $<0.001$ \\
\hline & & & Cardiovascular & $<0.001$ \\
\hline & & & Stroke & $<0.001$ \\
\hline & & & Nutritional state & 0.017 \\
\hline & & & Polypharmacy & $<0.001$ \\
\hline & & & Self-rated health & $<0.001$ \\
\hline \multirow[t]{3}{*}{ E. Moudi et al. 2017 [34] } & Iran & Cross-sectional & Marital status & 0.03 \\
\hline & & & Constipation & 0.01 \\
\hline & & & Steroid drug & 0.04 \\
\hline \multirow[t]{6}{*}{ David V. Espino et al. 2003 [36] } & Mexico & Cross-sectional & Education & 0.03 \\
\hline & & & BMl & 0.03 \\
\hline & & & Diabetes & 0.01 \\
\hline & & & Smoking & $<0.001$ \\
\hline & & & $\begin{array}{l}\text { Impaired activities of } \\
\text { daily living }\end{array}$ & 0.03 \\
\hline & & & Age & 0.02 \\
\hline \multirow[t]{10}{*}{ Stefania Maggi et al. 2001 [37] } & Italy & Cross-sectional & Age & $<0.001$ \\
\hline & & & Marital status & $<0.001$ \\
\hline & & & Education & $<0.001$ \\
\hline & & & Mental Health & $<0.001$ \\
\hline & & & Depression & 0.028 \\
\hline & & & Mobility disability & $<0.001$ \\
\hline & & & ADL disability & $<0.001$ \\
\hline & & & BMI & $<0.001$ \\
\hline & & & Smoking & $<0.001$ \\
\hline & & & Self-rated health & $<0.001$ \\
\hline \multirow{10}{*}{$\begin{array}{l}\text { Marit Helen Ebbesen et al. } \\
2013 \text { [60] }\end{array}$} & Norway & Cross-sectional & Age & $<0.001$ \\
\hline & & & BMI & $<0.001$ \\
\hline & & & Self-perceived health status & $<0.001$ \\
\hline & & & Smoking & 0.009 \\
\hline & & & Alcohol & 0.016 \\
\hline & & & Parity & $<0.001$ \\
\hline & & & Diabetes & 0.029 \\
\hline & & & Angina & 0.021 \\
\hline & & & Heart attack & 0.047 \\
\hline & & & Stroke & 0.032 \\
\hline $\begin{array}{l}\text { Clemens Wehrberger et al. } \\
2012 \text { [68] }\end{array}$ & Austria & $\begin{array}{l}\text { longitudinal, } \\
\text { population-based study }\end{array}$ & Alzheimer & 0.073 \\
\hline \multirow[t]{7}{*}{ Jeongok Park et al. 2015 [66] } & Korea & Analytical descriptive & Age & $<0.001$ \\
\hline & & & BMI & 0.02 \\
\hline & & & Place of residence & 0.003 \\
\hline & & & Self-reported health status & $<0.001$ \\
\hline & & & Hypertension & $<0.001$ \\
\hline & & & Stroke & $<0.001$ \\
\hline & & & Diabetes & $<0.001$ \\
\hline
\end{tabular}


Table 3 A systematic review of the factors affecting older adults' women with urinary incontinence (Continued)

\begin{tabular}{|c|c|c|c|c|}
\hline Author [References] & Place of study & type of study & Risk factors examined & $p$-value \\
\hline & & & Asthma & $<0.001$ \\
\hline & & & Depress & $<0.001$ \\
\hline & & & Falls & $<0.001$ \\
\hline & & & Functional ability & $<0.001$ \\
\hline & & & Physical strength & $<0.001$ \\
\hline \multirow[t]{25}{*}{ Jing Ge et al. 2015 [39] } & China & Analytical descriptive & Age & $<0.001$ \\
\hline & & & Job & $<0.001$ \\
\hline & & & Education & $<0.001$ \\
\hline & & & BMl & $<0.001$ \\
\hline & & & Income/month & 0.014 \\
\hline & & & Smoking & 0.023 \\
\hline & & & Physical exercise frequency & $<0.001$ \\
\hline & & & Menstrual status & $<0.001$ \\
\hline & & & Pregnancy history & $<0.001$ \\
\hline & & & Abortion times & $<0.001$ \\
\hline & & & Parity & $<0.001$ \\
\hline & & & Age at first delivery & $<0.001$ \\
\hline & & & Mode of delivery & $<0.001$ \\
\hline & & & Chronic pelvic pain & $<0.001$ \\
\hline & & & Respiratory disease & $<0.001$ \\
\hline & & & Digestive disease & $<0.001$ \\
\hline & & & Cardiovascular & $<0.001$ \\
\hline & & & Neurologic disease & 0.003 \\
\hline & & & Osteoarticular disease & $<0.001$ \\
\hline & & & Hyperlipemia & $<0.001$ \\
\hline & & & Diabetes & $<0.001$ \\
\hline & & & History of pelvic surgery & $<0.001$ \\
\hline & & & Gynecological disease & $<0.001$ \\
\hline & & & Constipation & $<0.001$ \\
\hline & & & Fecal incontinence & $<0.001$ \\
\hline \multirow[t]{2}{*}{ Juliana Schulze Burti et 2012 [40] } & Brazil & Cross-sectional & Diabetes & 0.022 \\
\hline & & & hypertension & 0.008 \\
\hline \multirow[t]{2}{*}{ Joshua A. Cohn et al. 2018 [61] } & USA & Cohort & Age & $<0.001$ \\
\hline & & & Education & 0.034 \\
\hline \multirow[t]{9}{*}{ Vatche A. Minassian et al. 2020 [62] } & USA & Cohort & Age & $<0.001$ \\
\hline & & & $\mathrm{BMl}$ & $<0.001$ \\
\hline & & & Parity & $<0.001$ \\
\hline & & & Smoking & $<0.001$ \\
\hline & & & Physical activity & $<0.001$ \\
\hline & & & Diabetes & $<0.001$ \\
\hline & & & History of vascular disease & $<0.001$ \\
\hline & & & Postmenopausal hormone use & $<0.001$ \\
\hline & & & Baseline UI severity & $<0.001$ \\
\hline
\end{tabular}


Table 3 A systematic review of the factors affecting older adults' women with urinary incontinence (Continued)

\begin{tabular}{|c|c|c|c|c|}
\hline Author [References] & Place of study & type of study & Risk factors examined & $p$-value \\
\hline \multirow[t]{6}{*}{ MáyraCeciliaDellú et al. 2016 [63] } & Brazil & Cross-sectional & Pregnancy & $<0.001$ \\
\hline & & & Post-partum & $<0.001$ \\
\hline & & & Genital prolapse & $<0.001$ \\
\hline & & & Stress & $<0.001$ \\
\hline & & & Depression & $<0.001$ \\
\hline & & & BMI & $<0.001$ \\
\hline \multirow[t]{3}{*}{ Javier Jerez-Roig et al. 2016 [46] } & Brazil & Cross-sectional & Ethnicity & 0.005 \\
\hline & & & Stroke & 0.003 \\
\hline & & & Physical activity & 0.03 \\
\hline \multirow[t]{7}{*}{ Ramazan Altintas et al. 2013 [67] } & Turkey & Retrospective study & Age & $<0.001$ \\
\hline & & & BMl & $<0.001$ \\
\hline & & & Parity & $<0.001$ \\
\hline & & & hypertension & 0.008 \\
\hline & & & Diabetes & $<0.001$ \\
\hline & & & Birth trauma & $<0.001$ \\
\hline & & & Gynecological surgery & $<0.001$ \\
\hline \multirow[t]{10}{*}{ Nazli Sensoy et al. 2013 [48] } & Turkey & Cross-sectional & Age & $<0.001$ \\
\hline & & & Marital status & $<0.001$ \\
\hline & & & Education & $<0.001$ \\
\hline & & & Job & $<0.001$ \\
\hline & & & BMl & $<0.001$ \\
\hline & & & Number of Deliveries & $<0.001$ \\
\hline & & & Episiotomy & $<0.001$ \\
\hline & & & Abortion & $<0.001$ \\
\hline & & & Age at first delivery & $<0.001$ \\
\hline & & & $4 \mathrm{~kg}$ baby delivered & $<0.001$ \\
\hline \multirow[t]{10}{*}{ J. Marleen Linde et al. 2017 [49] } & Netherlands & Cross-sectional & Age & $<0.001$ \\
\hline & & & BMl & $<0.001$ \\
\hline & & & UTI & $<0.001$ \\
\hline & & & Nocturia & 0.04 \\
\hline & & & Fecal incontinence & 0.004 \\
\hline & & & Constipation & $<0.001$ \\
\hline & & & Diabetes & $<0.001$ \\
\hline & & & Vaginal hysterectomy & $<0.001$ \\
\hline & & & Childbirth history & $<0.001$ \\
\hline & & & Number of deliveries & $<0.001$ \\
\hline \multirow[t]{8}{*}{ Bo Liu et al. 2014 [52] } & China & Cross-sectional & BMI & $<0.001$ \\
\hline & & & Monthly Income & $<0.001$ \\
\hline & & & Education & $<0.001$ \\
\hline & & & Residence & $<0.001$ \\
\hline & & & Physical activity & $<0.001$ \\
\hline & & & Labor & $<0.001$ \\
\hline & & & Physical activity & $<0.001$ \\
\hline & & & Hyperlipemia & $<0.001$ \\
\hline
\end{tabular}


Table 3 A systematic review of the factors affecting older adults' women with urinary incontinence (Continued)

\begin{tabular}{|c|c|c|c|c|}
\hline Author [References] & Place of study & type of study & Risk factors examined & $p$-value \\
\hline & & & Cardiovascular & $<0.001$ \\
\hline & & & Nervous System Disease & $<0.001$ \\
\hline & & & Diabetes & $<0.001$ \\
\hline & & & Nocturia & $<0.001$ \\
\hline & & & Constipation & $<0.001$ \\
\hline & & & Alcohol & $<0.001$ \\
\hline & & & Smoking & $<0.001$ \\
\hline & & & Prolonged Labor & $<0.001$ \\
\hline & & & Chronic pelvic pain & $<0.001$ \\
\hline & & & Marital status & $<0.001$ \\
\hline & & & Respiratory disease & $<0.001$ \\
\hline & & & Pregnancy & $<0.001$ \\
\hline & & & UTI & $<0.001$ \\
\hline & & & Mode of delivery & $<0.001$ \\
\hline \multirow[t]{5}{*}{ Walaa W. Aly et al. 2020 [50] } & Egypt & Cross-sectional & Praying & $<0.001$ \\
\hline & & & Social activities & $<0.001$ \\
\hline & & & Physical recreational activities & 0.002 \\
\hline & & & Anxiety & $<0.001$ \\
\hline & & & Depression/hopelessness & $<0.001$ \\
\hline
\end{tabular}

recommended by the International Continence Society (ICS) and to standardize the criteria so that diagnostic and treatment strategies are more effective.

\section{Limitations}

The most important limitations of the present study are the high heterogeneity of studies, which can be due to sampling size, age groups, geographical areas, races, and other different factors in the studies, which can be controversial in the study.

\section{Conclusion}

Given the high prevalence of urinary incontinence in older women around the world, health policy makers must considerand diagnostic measures in older women and prioritize treatment and rehabilitation activities.

\footnotetext{
Abbreviations

WHO: World Health Organization; ICS: International Association of Urinary Incontinence; UI: urinary incontinence; SUI: Stress urinary incontinence; UUI: Urgent urinary incontinence; NOS: The Newcastle-Ottawa Scale; SID: Scientific information database; PRISMA: Preferred reporting items for systematic reviews and meta-analysis; STROBE: Strengthening the reporting of observational studies in epidemiology for cross- sectional study
}

\section{Acknowledgements}

We hereby express our gratitude and appreciation to the school of nursing and midwifery of Kermanshah university of medical sciences.

\section{Authors' contributions}

RJ and SB1 and MM contributed to the design, MM statistical analysis, participated in most of the study steps. SB1 and MM prepared the manuscript. SB1 and RJ and SB2 assisted in designing the study, and helped in the, interpretation of the study. All authors have read and approved the content of the manuscript.

\section{Funding}

Funding for this research was provided by the deputy of research and technology -Kermanshah University of Medical Sciences, (990423), the deputy of research and technology -Kermanshah University of Medical Sciences had no role in the design of the study and collection, analysis, and interpretation of data and in writing of the manuscript.

\section{Availability of data and materials}

Datasets are available through the corresponding author upon reasonable request.

\section{Declarations}

Ethics approval and consent to participate

This study was recorded in the ethics committee of Kermanshah University of medical sciences with the ethics code of (IR.KUMS.REC.1399.455).

\section{Consent for publication}

Not applicable.

\section{Competing interests}

The authors declare that they have no conflict of interest.

\section{Author details}

'Department of Nursing, School of Nursing and Midwifery, Kermanshah University of Medical Sciences, Kermanshah, Iran. ${ }^{2}$ Faculty of Health and Life Sciences, School of Life Sciences, Coventry University, Coventry, UK. 
Received: 11 August 2020 Accepted: 7 March 2021 Published online: 29 March 2021

\section{References}

1. Vaisi-Raygani AA, Mohammadi M, Jalali R, Ghobadi A, Salari N. The prevalence of obesity in older adults in Iran: a systematic review and metaanalysis. BMC Geriatr. 2019;19(1):371

2. Lukacz ES, Santiago-Lastra Y, Albo ME, Brubaker L. Urinary incontinence in women: a review. JAMA. 2017;318(16):1592-604. https://doi.org/10.1001/ja ma.2017.12137.

3. Hu JS, Pierre EF. Urinary Incontinence in Women: Evaluation and Management. Am Fam Physician. 2019;100(6):339-48.

4. Forde JC, Chughtai B, Cea M, Stone BV, Te A, Bishop TF. Trends in ambulatory management of urinary incontinence in women in the United States. Female Pelvic Med Reconstr Surg. 2017;23(4):250-5. https://doi.org/1 0.1097/SPV.0000000000000365.

5. Peate I. Urinary incontinence in women: treatment recommendations. $\mathrm{Br}$ J Nurs. 2019:28(22):1486-8. https://doi.org/10.12968/bjon.2019.28.22.1486.

6. Barat $S$, Javadian $Y$, Talebi G, Aghajani M. Frequency of urinary incontinence in female patients attending pelvic floor disorders clinic. J Mazandaran Univ Med Sci. 2015;24(121):189-96.

7. Nygaard IE, Shaw JM. Physical activity and the pelvic floor. Am J Obstet Gynecol. 2016;214(2):164-71. https://doi.org/10.1016/j.ajog.2015.08.067.

8. Agarwal BK, Agarwal N. Urinary incontinence: prevalence, risk factors, impac on quality of life and treatment seeking behaviour among middle aged women. Int Surg J. 2017:4(6):953-8.

9. Javadifar N, Komeilifar R, Afshary P, Haghighy M. Urinary incontinence and its predisposing factors in reproductive age women. Sci J llam Univ Med Sci. 2016;25(6):45-53.

10. Goforth J, Langaker M. Urinary incontinence in women. N C Med J. 2016; 77(6):423-5. https://doi.org/10.18043/ncm.77.6.423

11. Lim Y-M, Lee SR, Choi EJ, Jeong K, Chung HW. Urinary incontinence is strongly associated with depression in middle-aged and older Korean women: data from the Korean longitudinal study of ageing. Eur J Obstetr Gynecol Reprod Biol. 2018;220:69-73. https://doi.org/10.1016/j.ejogrb.201 7.11.017.

12. Melotti IGR, Juliato CRT, Tanaka M, Riccetto CLZ. Severe depression and anxiety in women with overactive bladder. Neurourol Urodyn. 2018;37(1): 223-8. https://doi.org/10.1002/nau.23277.

13. Winkelman WD, Warsi A, Huang AJ, Schembri M, Rogers RG, Richter HE, Myers DL, Kraus SR, Johnson KC, Hess R, Gregory T, Bradley CS, Arya LA, Brown JS, Stone KL, Subak LL. Sleep quality and daytime sleepiness among women with urgency predominant urinary incontinence. Female Pelvic Med Reconstr Surg. 2018;24(2):76-81. https://doi.org/10.1097/SPV. 0000000000000547.

14. Gibson W, Hunter KF, Camicioli R, Booth J, Skelton DA, Dumoulin C, Paul L, Wagg A. The association between lower urinary tract symptoms and falls: forming a theoretical model for a research agenda. Neurourol Urodyn. 2018; 37(1):501-9. https://doi.org/10.1002/nau.23295

15. Soliman $Y$, Meyer $R$, Baum N. Falls in the elderly secondary to urinary symptoms. Rev Urol. 2016;18(1):28-32.

16. Lim $\mathrm{R}$, Liong $\mathrm{ML}$, Leong WS, Lau YK, Khan NAK, Yuen $\mathrm{KH}$. The impact of stress urinary incontinence on individual components of quality of life in Malaysian women. Urology. 2018;112:38-45. https://doi.org/10.1016/j. urology.2017.10.019.

17. Tzur $T$, Yohai $D$, Weintraub AY. The role of local estrogen therapy in the management of pelvic floor disorders. Climacteric. 2016;19(2):162-71. https://doi.org/10.3109/13697137.2015.1132199.

18. Nasaj G, Omidpour P, Shah Ali S, ZS. Relationship between pelvic floor muscle strength and severity of urinary incontinence on quality of life in women with urinary incontinence; 2017.

19. Schneeweiss J, Koch M, Umek W. The human urinary microbiome and how it relates to urogynecology. Int Urogynecol J. 2016;27(9):1307-12. https:// doi.org/10.1007/s00192-016-2944-5

20. Pearce MM, Zilliox MJ, Rosenfeld AB, Thomas-White KJ, Richter HE, Nager $\mathrm{CW}$, et al. The female urinary microbiome in urgency urinary incontinence. Am J Obstetr Gynecol. 2015;213(3):347. e1-. e1.

21. Alpoim PN, de Barros PM, Junqueira DR, Freitas LG, das Gracas Carvalho M, Fernández AP, et al. Preeclampsia and ABO blood groups: a systematic review and metaanalysis. Mol Biol Rep. 2012;40:2253-61.
22. Suskind AM, Cawthon PM, Nakagawa S, Subak LL, Reinders I, Satterfield S, Cummings S, Cauley JA, Harris T, Huang AJ, Health ABC Study. Urinary incontinence in older women: the role of body composition and muscle strength: from the health, aging, and body composition study. J Am Geriatr Soc. 2017;65(1):42-50. https://doi.org/10.1111/jgs.14545.

23. Marques LP, Schneider IJC, Giehl MWC, Antes DL, d'Orsi E. Demographic, health conditions, and lifestyle factors associated with urinary incontinence in elderly from Florianópolis, Santa Catarina, Brazil. Rev Bras Epidemiol. 2015; 18(3):595-606. https://doi.org/10.1590/1980-5497201500030006.

24. Stickley A, Santini ZI, Koyanagi A. Urinary incontinence, mental health and Ioneliness among community-dwelling older adults in Ireland. BMC Urol. 2017;17(1):29. https://doi.org/10.1186/s12894-017-0214-6.

25. Suhr $\mathrm{R}$, Lahmann NA. Urinary incontinence in home care: a representative multicenter study on prevalence, severity, impact on quality of life, and risk factors. Aging Clin Exp Res. 2018;30(6):589-94. https://doi.org/10.1007/s4052 0-017-0816-6.

26. Sohn K, Lee CK, Shin J, Lee J. Association between female urinary incontinence and geriatric health problems: results from Korean longitudinal study of ageing (2006). Korean J Fam Med. 2018;39(1):10-4 https://doi.org/10.4082/kjfm.2018.39.1.10.

27. Eshkoor S, Hamid TA, Shahar S, Mun C. Factors related to urinary incontinence among the Malaysian elderly. J Nutr Health Aging. 2017;21(2): 220-6. https://doi.org/10.1007/s12603-016-0779-x.

28. Gallas $S$, Frioui $S$, Rabeh $H$, Rejeb MB. Prevalence and risk factors for urinary and anal incontinence in Tunisian middle aged women. Afr J Urol. 2018; 24(4):368-73. https://doi.org/10.1016/j.afju.2018.08.002.

29. Kaşıkçı M, Kılıç D, Avşar G, Şirin M. Prevalence of urinary incontinence in older Turkish women, risk factors, and effect on activities of daily living. Arch Gerontol Geriatr. 2015;61(2):217-23. https://doi.org/10.1016/j.archger.2 015.06.008.

30. Khan S, Ansari MA, Vasenwala SM, Mohsin Z. The influence of menopause on urinary incontinence in the women of the community: a cross-sectional study from North India. Int J Reprod Contracept Obstetr Gynecol. 2017;6(3): 911-8. https://doi.org/10.18203/2320-1770.ijrcog20170555.

31. Morowatisharifabad MA, Rezaeipandari H, Mazyaki A, Bandak Z. Prevalence of urinary incontinence among elderly women in Yazd, Iran: a populationbased study. Elderly Health J. 2015;1(1):27-31.

32. Bijani A, Ghadimi R, Mikaniki E. Cohort Profile Update: The Amikola Health and Ageing Project. Caspian J Intern Med. 2017;8(3):205-12 The original cohort The Amirkola Health and Ageing Project (AHAP) is the first comprehensive cohort project of the elderly in Iran (1) that composed.1616:2011-2.

33. Townsend MK, Lajous M, Medina-Campos RH, Catzin-Kuhlmann A, LópezRidaura R, Rice MS. Risk factors for urinary incontinence among postmenopausal Mexican women. Int Urogynecol J. 2017;28(5):769-76. https://doi.org/10.1007/s00192-016-3196-0.

34. Moudi E, Samadi F, Hosseini SR, Bijani A, Ghadimi R. Urinary incontinency in elderly women and the potential risk factors: a cohort study among the elderly women of Amirkola. J Babol Univ Med Sci. 2017;19(2):14-9.

35. Khanighaleejogh R, Akbari Kaji M, Shamsi A, Norrighoshki H. Prevalence of Urinary Tract Disorders in Residents of Kahrizak Elderly House. J Fac Nurs Midwifery. 2011;17:No 2.

36. Espino DV, Palmer RF, Miles TP, Mouton CP, Lichtenstein MJ, Markides KP. Prevalence and severity of urinary incontinence in elderly MexicanAmerican women. J Am Geriatr Soc. 2003;51(11):1580-6. https://doi.org/10.1 046/j.1532-5415.2003.51503.x.

37. Maggi S, Minicuci N, Langlois J, Pavan M, Enzi G, Crepaldi G. Prevalence rate of urinary incontinence in community-dwelling elderly individuals: the Veneto study. J Gerontol Ser A Biol Med Sci. 2001;56(1):M14-M8. https://doi. org/10.1093/gerona/56.1.M14.

38. Ko Y, Lin S-J, Salmon JW, Bron MS. The impact of urinary incontinence on quality of life of the elderly. Am J Manag Care. 2005;11(4 Suppl):S103-11.

39. Ge J, Yang $P$, Zhang Y, Li X, Wang Q, Lu Y. Prevalence and risk factors of urinary incontinence in Chinese women: a population-based study. Asia Pac J Public Health. 2015;27(2):NP1118-NP31. https://doi.org/10.1177/101053 9511429370.

40. Burti JS, Santos AMB, Pereira RMR, Zambon JP, Marques AP. Prevalence and clinical characteristics of urinary incontinence in elderly individuals of a low income. Arch Gerontol Geriatr. 2012;54(2):e42-e6. https://doi.org/10.1016/j.a rchger.2011.04.004

41. Sumardi R, Mochtar CA, Junizaf J, Santoso BI, Setiati S, Nuhonni SA, et al. Prevalence of urinary incontinence, risk factors and its impact: multivariate 
analysis from Indonesian nationwide survey. Acta medica Indonesiana. 2016; 46(3):175-82.

42. Masenga GG, Shayo BC, Msuya S, Rasch V. Urinary incontinence and its relation to delivery circumstances: a population-based study from rural Kilimanjaro, Tanzania. Plos one. 2019;14(1):e0208733. https://doi.org/10.1371/ journal.pone.0208733.

43. Wu JM, Matthews CA, Vaughan CP, Markland AD. Urinary, fecal, and dual incontinence in older US adults. J Am Geriatr Soc. 2015;63(5):947-53. https://doi.org/10.1111/jgs.13385.

44. Zhang L, Zhu L, Xu T, Lang J, Li Z, Gong J, Liu Q, Liu X. A population-based survey of the prevalence, potential risk factors, and symptom-specific bother of lower urinary tract symptoms in adult Chinese women. Eur Urol. 2015; 68(1):97-112. https://doi.org/10.1016/j.eururo.2014.12.012.

45. Pinkas J, Gujski M, Humeniuk E, Raczkiewicz D, Bejga P, Owoc A, Bojar I. State of health and quality of life of women at advanced age. Med Sci Monit. 2016;22:3095-105. https://doi.org/10.12659/MSM.900572.

46. Jerez-Roig J, Santos MM, Souza DL, Amaral FL, Lima KC. Prevalence of urinary incontinence and associated factors in nursing home residents. Neurourol Urodyn. 2016;35(1):102-7. https://doi.org/10.1002/nau.22675.

47. Reigota RB, Pedro AO, de Souza Santos Machado V, Costa-Paiva L, PintoNeto AM. Prevalence of urinary incontinence and its association with multimorbidity in women aged 50 years or older: a population-based study. Neurourol Urodyn. 2016;35(1):62-8. https://doi.org/10.1002/nau.22679.

48. Sensoy N, Dogan N, Ozek B, Karaaslan L. Urinary incontinence in women: prevalence rates, risk factors and impact on quality of life. Pak J Med Sci. 2013;29(3):818-22. https://doi.org/10.12669/pjms.293.3404.

49. Linde JM, Nijman RJ, Trzpis M, Broens PM. Urinary incontinence in the Netherlands: prevalence and associated risk factors in adults. Neurourol Urodyn. 2017;36(6):1519-28. https://doi.org/10.1002/nau.23121.

50. Aly WW, Sweed HS, Mossad NA, Tolba MF. Prevalence and risk factors of urinary incontinence in frail elderly females. J Aging Res. 2020;2020:1-8. https://doi.org/10.1155/2020/2425945.

51. Prabhu SA, Shanbhag S. Prevalence and risk factors of urinary incontinence in women residing in a tribal area in Maharashtra, India; 2013.

52. Liu B, Wang L, Huang S-S, Wu Q, Wu D-L. Prevalence and risk factors of urinary incontinence among Chinese women in Shanghai. Int J Clin Exp Med. 2014;7(3):686-96.

53. Ramage-Morin PL, Gilmour H. Urinary incontinence and loneliness in Canadian seniors: Statistics Canada. Health Rep. 2013;24(10):3-10.

54. Luo R, Dai W, Tay LH, Ng FC, Koh L-T. Urinary incontinence in female outpatients in Singapore. Int Urogynecol J. 2018;29(4):579-84. https://doi. org/10.1007/s00192-017-3488-z.

55. Matthews CA, Whitehead WE, Townsend MK, Grodstein F. Risk factors for urinary, fecal or dual incontinence in the nurses' health study. Obstet Gynecol. 2013;122(3):539-45. https://doi.org/10.1097/AOG.0b013e31829efbff.

56. Schumpf LF, Theill N, Scheiner DA, Fink D, Riese F, Betschart C. Urinary incontinence and its association with functional physical and cognitive health among female nursing home residents in Switzerland. BMC Geriatr. 2017;17(1):17. https://doi.org/10.1186/s12877-017-0414-7.

57. Tkacheva ON, Runikhina NK, Ostapenko VS, Sharashkina NV, Mkhitaryan EA, Onuchina JS, Lysenkov SN, Yakhno NN, Press Y. Prevalence of geriatric syndromes among people aged 65 years and older at four community clinics in Moscow. Clin Interv Aging. 2018;13:251-9. https://doi.org/10.2147/ CIA.S153389

58. Schreiber Pedersen L, Lose G, Høybye MT, Elsner S, Waldmann A, Rudnicki M. Prevalence of urinary incontinence among women and analysis of potential risk factors in Germany and Denmark. Acta Obstet Gynecol Scand. 2017;96(8):939-48. https://doi.org/10.1111/aogs.13149.

59. Ninomiya S, Naito K, Nakanishi K, Okayama H. Prevalence and risk factors of urinary incontinence and overactive bladder in $J$ apanese women. LUTS. 2018;10(3):308-14. https://doi.org/10.1111/luts.12185.

60. Ebbesen MH, Hunskaar S, Rortveit G, Hannestad YS. Prevalence, incidence and remission of urinary incontinence in women: longitudinal data from the Norwegian HUNT study (EPINCONT). BMC Urol. 2013;13(1):27. https:// doi.org/10.1186/1471-2490-13-27.

61. Cohn JA, Shah AS, Goggins KM, Simmons SF, Kripalani S, Dmochowski RR, Schnelle JF, Reynolds WS. Health literacy, cognition, and urinary incontinence among geriatric inpatients discharged to skilled nursing facilities. Neurourol Urodyn. 2018;37(2):854-60. https://doi.org/10.1002/na u.23368.
62. Minassian VA, Hagan KA, Erekson E, Austin AM, Carmichael D, Bynum JP et al. The natural history of urinary incontinence subtypes in the Nurses' Health Studies. Am J Obstetr Gynecol. 2020;222(2):163. e1-8.

63. Dellú MC, Schmitt ACB, Cardoso MRA, Pereira WMP, Pereira ECA, Vasconcelos ÉSF, et al. Prevalence and factors associated with urinary incontinence in climacteric. Rev Assoc Méd Bras. 2016;62(5):441-6. https:// doi.org/10.1590/1806-9282.62.05.441.

64. Rashidi F, Hajian S, Darvish S, Alavi MH. Prevalence of urinary incontinence in Iranian women: systematic review and meta-analysis. Iran J Obstetr Gynecol Infertility. 2019;21(12):94-102.

65. Lu S, Zhang H-L, Zhang Y-J, Shao Q-C. Prevalence and risk factors of urinary incontinence among perimenopausal women in Wuhan. J Huazhong Univ Sci Technol. 2016;36(5):723-6.

66. Park J, Hong G-RS, Yang W. Factors associated with self-reported and medically diagnosed urinary incontinence among community-dwelling older women in Korea. Int Neurourol J. 2015;19(2):99-106. https://doi.org/10. 5213/inj.2015.19.2.99.

67. Altintas R, Beytur A, Oguz F, Tasdemir C, Kati B, Cimen S, Colak C, Gunes A. Assessment of urinary incontinence in the women in eastern Turkey. Int Urogynecol J. 2013;24(11):1977-82. https://doi.org/10.1007/ s00192-013-2137-4.

68. Wehrberger C, Madersbacher S, Jungwirth S, Fischer P, Tragl KH. Lower urinary tract symptoms and urinary incontinence in a geriatric cohort-a population-based analysis. BJU Int. 2012;110(10):1516-21. https://doi.org/1 0.1111/j.1464-410X.2012.11022.x.

69. Touhidi Nezhad F, Jalali R, Karimi F. Women's experiences of rectovaginal fistula: an ethno- religious experience. BMC Womens Health. 2020;20(1):130. https://doi.org/10.1186/s12905-020-00992-w.

70. Ramezanzadeh K, Sharifzadeh G, Saljughi M, Moodi M, Ibrahimzadeh A. An epidemiological study of the infectious diseases of older adults hospitalized in hospitals affiliated to Birjand University of Medical Sciences, in 2016. Iran J Ageing. 2019;14(3):298-309.

71. Traish AM, Vignozzi L, Simon JA, Goldstein I, Kim NN. Role of androgens in female genitourinary tissue structure and function: implications in the genitourinary syndrome of menopause. Sex Med Rev. 2018;6(4):558-71. https://doi.org/10.1016/j.sxmr.2018.03.005.

72. Vakili M, Amogadiri M, Mohammadi M, Modaressi M. Prevalence and factors associated with stress urinary incontinence after childbirth in Yazd in 2015. SSU_J. 2016;24(9):716-23.

73. Mansourghanaie $M$, Asgari A. Related factors associated with urinary incontinence in women who had cystocel and rectocel surgery. J Holistic Nurs Midwifery. 2015;25(1):73-7.

74. Hagan KA, Erekson E, Austin A, Minassian VA, Townsend MK, Bynum JP, et al. A prospective study of the natural history of urinary incontinence in women. Am J Obstetr Gynecol. 2018;218(5):502. e1-8.

75. Feeney C, Gorman G, Stefanetti R, McFarland R, Turnbull D, Harding C, Sachdeva A. Lower urinary tract dysfunction in adult patients with mitochondrial disease. Neurourol Urodyn. 2020;39(8):2253-63.

76. Burge AT, Lee AL, Kein C, Button B, Sherburn M, Miller B, et al. Prevalence and impact of urinary incontinence in men with chronic obstructive pulmonary disease: a questionnaire survey. Physiotherapy. 2017;103(1):53-8. https://doi.org/10.1016/j.physio.2015.11.004.

\section{Publisher's Note}

Springer Nature remains neutral with regard to jurisdictional claims in published maps and institutional affiliations.

\section{Ready to submit your research? Choose BMC and benefit from:}

- fast, convenient online submission

- thorough peer review by experienced researchers in your field

- rapid publication on acceptance

- support for research data, including large and complex data types

- gold Open Access which fosters wider collaboration and increased citations

- maximum visibility for your research: over $100 \mathrm{M}$ website views per year

At BMC, research is always in progress.

Learn more biomedcentral.com/submissions 